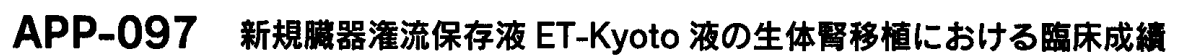

\section{京都大学医学部泌尿器科 ${ }^{1)}$, 京都大学医学部附属病院病理診断部 ${ }^{2)}$, 京都大学戥器機能保存学 ${ }^{3)}$}

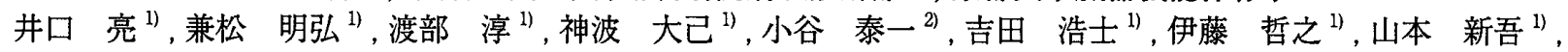

奥野 博 ${ }^{12}$, 中村 英二郎 ${ }^{1)}$, 賀本 敏行 ${ }^{12}$, 板東 徹 $^{3)}$, 小川 修 ${ }^{11}$

【目的】ET-Kyoto 液 (ETK 液) は、肺移植の臟器保存液として京都大学呼吸器外科および䠄器機能保存学講座で開発された新しい䐵器保存液である。 従来の Euro-Collins (EC) 液や University of Wisconsin (UW) 液が細胞内液組成に近いのに対して、ETK 液は細胞外液型組成に近く、トレハロース やグルコン酸などの独自の成分を含むことを特徴としている。現在では肺移植の他、膵島移植や形成外科領域での切断指再接着術などに臨床応用され ている。当科ではラットを用いた腎保存実験で、EC 液および UW 液との比較におけるETK 液の有用性を報告している (Transplantation. 2002)。こ れをふまえて2003年以降、計 15 例の生体腎移植術において ETK 液を灌流液として使用したので、その臨床的特徴を術後早期の腎機能の推移を中心 に検討した。方法】 2003 年 2 月から 2007 年 6 月までの間にETK 液を灌流液として用いた生体腎移植症例 15 例のうちデー夕解析不能であった 3 例 を除いた 12 例を対象とし、1999 年 8 月から 2002 年 8 月までの間に EC 液を灌流液として用いた生体腎移植症例 12 例を刘照群とした。術後早期（術 後1日目から 7 日目)の臨床デー夕を中心として比較検討を行った。また、単独の病理診断医により血流再開 1 時間後の腎生検組織の評価を行った。結

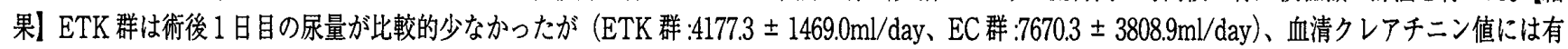
意な差はなく( $\mathrm{ETK}$ 群: $3.7 \pm 1.2 \mathrm{mg} / \mathrm{dl} 、 \mathrm{EC}$ 群 : $3.3 \pm 1.1 \mathrm{mg} / \mathrm{dl}$ )、逆に尿中クレアチニン漲度は有意に高功た ( $\mathrm{ETK}$ 群 $: 46.5 \pm 19.3 \mathrm{mg} / \mathrm{d} 、 \mathrm{EC}$ 群： $28.3 \pm 9.6 \mathrm{mg} / \mathrm{dl}$ )。また、ETK 群ではナトリウム排淠率（FENa）が有意に低加た（ETK 群: $2.9 \pm 1.5 \% 、 E C$ 群: $5.8 \pm 1.7 \%$ )。 EC 群の FENa は術

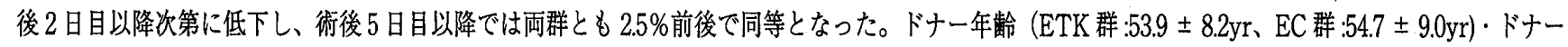
術後血清クレアチニン值 $(\mathrm{ETK}$ 群 $1.02 \pm 0.32 \mathrm{mg} / \mathrm{dl} 、 \mathrm{EC}$ 群 : $0.99 \pm 0.28 \mathrm{mg} / \mathrm{dl}$ )、レシピエント術中輸液量 (ETK 群: $1100 \pm 1224 \mathrm{ml} 、 \mathrm{EC}$ 群: $4483 \pm$ $1048 \mathrm{ml}$ )、初尿時間( $\mathrm{ETK}$ 群 $5.82 \pm 3.82 \mathrm{~min} 、 \mathrm{EC}$ 群: $6.25 \pm 3.55 \mathrm{~min}$ )梳同等だった。血流再開1時間後生検組織では、両群で明らかな相違点を認めなかった。 [考察】生体腎移植直後は、阻血再灌流による近位尿細管系の障害により Naの再吸収が阻害されることで多量の利尿がつくことが特有の現象であると 考えられてきた。しかしETK 液使用例では比較的少ない尿量でEC 液と同等のクレアチニン低下を示し、尿細管障害の指標である FENaが有意に低かっ たことより、ETK 液が術後早期の過剩利尿を抑制して、より生理的な腎機能発現を術後早期から可能としている可能性が示唆された。

\section{APP-098 ラット膀胱におけるA型ボツリヌス毒素のアポトーシス作用に関する模討一ボツリヌス毒素の腤胼壁内注射摬 法は膀胱萎縮を招く可能性があるか?一}

\section{鳥取大学医学部器官制御外科学講座腎泌尿器学分野}

渡邊 健志, 真砂 俊彦, 宮川 征男

【目的】我々は 2003 年より難治性の過活動膀胱に対してA型ボッリヌス毒素（BTX-A）の膀胱壁内注射療法を施行して おり、良好な成績を得ている。基礎的実験では BTX-A が前立腺のアポトーシスを誘導し前立腺重量を減少させている報 告があり、最近では前立腺肥大症の治療にも臨床応用されている。仮にBTX-A が排尿筋でもアポトーシスを誘導する のであれば、BTX-A 膀胱壁内注射療法の副作用として膀胱萎縮も考慮する必要がある。今回、我々は雄ラットを用いて BTX-A が膀胱壁内でアポトーシスを誘導しているか検討した。【方法】ペントバルビタール麻酔下にて、12 週齢の雄ラッ ト $(\mathrm{n}=8)$ の膀胱壁、前立腺側葉に BTX-A を、各々 5 単位 $/ 0.2 \mathrm{ml}$ ずつ注入した (BTX 群)。コントロール群 $(\mathrm{n}=8)$ には 同量の生理食塩水を注入した。2 週間後、膀胱、前立腺を摘出し、TUNEL 染色、PCNA 染色を施行した。また、定量 的RT-PCR 法により排尿筋の bcl-2, BAX 遺伝子のm RNA の発現量を検討した。結果】前立腺重量は B T X 群、コントロー ル群では有意差を認めなかったが、膀胱重量はコントロール群（平均 $0.13 \mathrm{~g} ） に$ 対し BTX群 $(0.29 \mathrm{~g}$ ) では有意に増加し ていた。TUNEL 染色では、BTX 群において膀胱粘膜、前立腺腺上皮で陽性細胞が散見されたが、コントロール群では ほとんど認めなかった。両群ともに排尿筋では陽性細胞を認めなかった。また、PCNA 染色では、BTX 群において膀胱 粘膜、排尿筋、前立腺腺上皮での陽性細胞がコントロール群に比べ有意に多かった。定量的 RT-PCR 法による検討では、 bcl-2, BAX ともに両群間で有意差を認めなかった。【考察】組織学的検討より、BTX-A が排尿筋のアポトーシスを誘導 する可能性は低いことが示唆された。また、両群間で bcl-2, BAX の発現量に有意差を認めないことも、この結果を支持 すると思われる。BTX 群で膀胱重量が増加した原因として、残尿増加に伴う過伸展が排尿筋の過形成を招いたのではな いかと推測している。以上の結果より、BTX-A 膀胱壁内注射療法が膀胱萎縮を招く可能性は低いと考えられた。 